\title{
THE EFFECT OF TRANS-URETHRAL SURGERY ON PENILE ERECTIONS IN SPINAL CORD INJURY PATIENTS
}

\author{
By D. G. Thомаs, F.R.C.S. \\ Consultant Urological Surgeon, Spinal Injuries Unit, Lodge Moor Hospital, Sheffield
}

\section{Introduction}

TRANSURETHRAL surgery on the external urethral sphincter or bladder neck and prostate is being used with increasing frequency and success in the urological management of spinal cord injury patients. Pudendal neurectomy to reduce external urethral sphincter spasm has been largely abandoned because of the uncertainty of the results and the effect on penile erections.

During the past four years, over 200 transurethral operations have been performed on patients in the Spinal Injuries Unit, Sheffield. Over this period a small number of patients have commented on a change in the pattern of their erections. These comments have led to this retrospective study on the effect of transurethral surgery on erections in a group of male patients with well established patterns of micturition and erection following spinal cord injury.

\section{Patients Studied and Surgery}

Sixty-two patients who had undergone transurethral surgery were considered to have well established patterns of micturition and erection. No patient who has had transurethral surgery within one year of spinal paralysis has been included. The time interval between spinal trauma and transurethral surgery varied from I to 26 years (average $8 \cdot 4$ years). Six of the 62 patients have been excluded from the results. One patient died of an unrelated cause, and one patient was treated with postoperative oestrogen therapy for prostatic malignancy. Four patients did not reply for follow-up (Table I).

In all cases surgery consisted of endoscopic division of the distal sphincteric mechanism including the external urethral sphincter. This was done using a knife electrode with the cutting diathermy current at three and nine o'clock. When

\section{TABLE I}

Erections following transurethral surgery

$\begin{array}{lc}\text { Total number of patients } & 62 \\ \begin{array}{ll}\text { Dead } & \text { I } \\ \text { CA. prostate } & \text { I } \\ \begin{array}{c}\text { No follow-up } \\ \text { Total studied }\end{array} & 6 \\ & \text { not included }\end{array} \\ -\overline{56}\end{array}$

Average interval from paralysis to transurethral surgery $-8 \cdot 4$ years 


\section{TABLE II}

Erections following transurethral surgery

$\left.\begin{array}{ll}\text { No erections before surgery } & \text { I3 } \\ \text { No change in erections } & \text { I9 } \\ \text { Erections abolished or diminished } & 24\end{array}\right\} 43$

TABLE III

Effect of transurethral surgery on patients with erections

Erections unchanged

Erections abolished or diminished

Total
I9 $(44 \%)$

$24(56 \%)$

43

Patients followed for more than one year (average $-2 \cdot 8$ years) 18 Patients followed for less than one year (average -6 months) 6

\section{TABLE IV}

Patients with no erections pre-op. (13)

$$
\text { Complete Partial }
$$
C-D4
D5-Dio
DII-L/S

$\begin{array}{ll}- & \\ 3 & 3\end{array}$

Reflex bladder-7. Atonic bladder -6 .

\section{TABLE V}

Patients with no change in erections (I9)

Complete Partial

$\begin{array}{llr}\text { C-D4 } & 6 & \text { I } \\ \text { D5-DIO } & 7 & - \\ \text { DiI-L/S } & 4 & \text { I }\end{array}$

Reflex bladder-I7. Atonic bladder-I.

\section{TABLE VI}

Erections abolished or diminished (24)

$$
\text { Complete Partial }
$$

$\begin{array}{lrr}\text { C-D4 } & \text { II } & \text { I } \\ \text { D5-DIo } & 7 & 2 \\ \text { DII-L/S } & 3 & -\end{array}$

Reflex bladder-22. Atonic bladder -2 . 
indicated by preoperative micturating cysto-urethrography either a bladder-neck incision or prostatic resection was also performed.

The effect of surgery in this group of 56 patients has been analysed.

\section{Results}

Of the 56 patients followed up, I3 (23 per cent) reported a complete absence of erections following spinal cord injury. Of the remaining 43 patients with established patterns of erection, I9 (44 per cent) observed no change following transurethral surgery. Twenty-four patients ( 56 per cent) reported that their erections had been permanently or temporarily altered following surgery. Eighteen of this group have been followed for more than one year (average 2.8 years) and six patients followed for less than one year (average six months) (Tables II and III).

Of the I3 patients with complete absence of erections following spinal cord injury, four had a neurological level between D.5 and D.IO. Nine of the patients had a level below D.I I (Table IV).

Table $\mathrm{V}$ shows the different neurological levels in the 19 patients with no change in erections following transurethral surgery. Fourteen patients had a level above D.Io.

Table VI shows the distribution of neurological levels in the 24 patients with a postoperative change in erections. The change was either a complete disappearance or diminution of erections (diminution in this context indicating a noticeable reduction in the frequency or strength or duration of erections or a combination of all three).

The neurological level was above D.IO in $2 \mathrm{I}$ of this group of 24 patients.

Eighteen patients with a postoperative change of erections have been followed up for more than one year (average $2 \cdot 8$ years). Four of these patients reported a total and permanent disappearance of erections (follow-up of three to four years). Ten patients noticed a permanent diminution in erections (follow-up of $I \cdot 5$ to 3.5 years) and four of these had a temporary total abolition of erections for periods varying between two months and two years followed by a gradual return of erections, but still diminished compared with their preoperative state. Erections returned to the preoperative state in only four of this group of 18 patients (Table VII).

Six patients of the group of 24 who noticed a postoperative change of erections have been followed up for the less than one year (average six months). Five of these patients have a complete disappearance of erections (follow-up of three to eight months) (Table VIII).

\section{Discussion}

The effect of transurethral surgery on erections in neurologically normal male patients is not widely documented. Windle and Roberts (1974) reported that in a group of 49 males undergoing transurethral surgery, seven patients (I 4 per cent) lost their erections in a follow-up varying from six months to 2.5 years. Of equal interest was the fact that in a group of 90 patients undergoing inguino-scrotal and intraperitoneal surgery, acting as a control group, five patients (six per cent) lost their erections.

Our results indicate that transurethral surgery in spinal cord injury patients carries a higher risk of temporary or permanent change in erections ( 56 per cent of 43 patients). 


\section{TABLE VII}

Patients with erections abolished or diminished

$\begin{array}{lr}\text { (Follow-up-more than I year (av.-2.8) } & \text { I8 } \\ \text { Permanently abolished (3-4 years) } & 4 \\ \text { Permanently diminished }(\mathrm{I} \cdot 5-3 \cdot 5 \text { years) } & \text { I0 } \\ \text { Temporary change with return to pre-op state } & \\ \quad \text { (3 months-2.5 years) } & 4\end{array}$

TABLE VIII

Patients with erections abolished or diminished

Follow-up for less than I year (av. -6 months) 6 Totally abolished 5

Diminished

In a group of neurologically normal patients quoted by Windle and Roberts the transurethral surgery was confined to the area proximal to the distal sphincteric mechanism, whereas in all our patients a distal sphincterotomy was performed. This may be one factor in the aetiology of the different observed results, but basically the mechanism is not understood.

\section{SUMMARY}

The effect of transurethral surgery on penile erections in 62 spinal cord injury patients is reviewed. In a group of 43 patients with preoperative erections, I 9 noticed no change in the pattern of erections. Twenty-four of the 43 patients notice either a diminution or total disappearance.

\section{RÉsUMÉ}

Les auteurs rapportent les effets de la chirurgie transuré-trale sur les érections de 62 traumatisés médullaires. Sur 43 patients avec des érections préopératoires I 9 ne notèrent aucun changement. Vingt-quatre des 43 patients constatèrent soit une diminution soit une disparition complète de leurs érections.

\section{ZUSAMMENFAUSSUNG}

In 62 Querschnittsgelähmten haben die Autoren die Wirkung von transurethralen Eingriffen an Erektionen studiert. Unter 43 Patienten mit preoperativen Erektionen haben I 9 keine Modifikation beobachtet. Unter 43 Patienten haben 24 entweder eine Herabsetzung oder ein Verschwinden von Erektionen bemerkt.

\section{REFERENCE}

WINDLE, R. \& RoBeRTS, J. B. M. (1974). Ejaculatory function after prostatectomy. Proc. Roy. Soc. Med. 67, II60-I I62. 